\title{
Influence of keeping technology on the weight gain of the Aberdeen-Angus breed young animals in the colostrum period
}

\author{
A.I. Dydykina ${ }^{1 *} \square^{D}$, V.H. Prudnikov ${ }^{1}{ }^{D}$, O.I. Kolisnyk ${ }^{1}{ }^{D}$, Y.O. Vasylieva ${ }^{1} \varangle(D$,

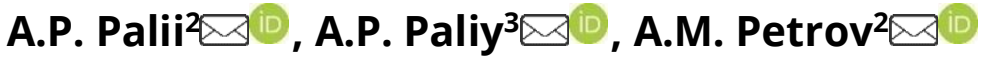 \\ ${ }^{1}$ Kharkiv State Zooveterinary Academy \\ 1 Academic St., Mala Danylivka, Dergachi district, Kharkiv region, 62341, Ukraine. \\ ${ }^{2}$ Kharkiv Petro Vasylenko National Technical University of Agriculture, \\ 44 Alchevskih St., Kharkiv, 61002, Ukraine. \\ ${ }^{3}$ National Scientific Center "Institute of Experimental and Clinical Veterinary Medicine", \\ 83 Pushkinska St., Kharkiv, 61023, Ukraine. \\ *Corresponding author E-mail: dydykina@ukr.net \\ Received: 10.01.2021. Accepted 22.03.2021
}

\begin{abstract}
In beef cattle breeding, unlike dairy farming, the only product is a calf. Therefore, the industry's competitiveness directly depends on the annual retention from each cow and heifer calf, the preservation of calves, and the high growth energy of young animal growth throughout the rearing period. These indicators are influenced by many factors, one of which is the breeding technology. The colostrum period is the most critical; newborn calves that do not receive adequate attention at the beginning of this period die within the first two days of life or have growth retardation. Given this, it becomes urgent to establish the level of dependence between young animals' growth and the technology of keeping cows and calves during the colostrum period. The studies were performed on cows and calves of the Aberdeen-Angus breed having problems in interaction during the colostrum period due to a weak maternal instinct in cows or a sucking reflex in calves (problem pairs' cow-calf). The growth rates of bull-calves and heifers were studied: live body weight, average daily gains, absolute gains, and multiplicity of live weight gain. The factor of a new technological element - the transfer of problem pairs' cow-calf into correction sections, in the colostrum period, on the further growth of young growth was analyzed. Our studies have shown a potential difference $(P>0.999)$ between the live weight of bull-calves, which in the colostrum period were transferred together with the cows to the correction sections, and those for which no correction sections were used. The advantage in live weight at the age of 18 months is $27 \%$ and $28 \%(P>0.999)$ in favor of bull-calves that were transferred; they prevailed by $28 \%(P>0.999)$ in average daily gains, and by $28 \%$ and $29 \%(P>0.999)$ in absolute terms. When compared by live weight at the age of 18 months, the heifers, which had been transferred to correction sections during the colostrum period, had an advantage of $26 \%$. The average daily and absolute gains in these heifers were $29 \%$ greater than the heifers, which were not transferred.
\end{abstract}

Keywords: beef cattle breeding; retention technology; cows; bull-calf; heifers

\section{Introduction}

Livestock farming plays an essential role in many countries' agro-industrial complex (Alhas et al., 2020; Korobkov et al., 2020; Palii \& Palii, 2019); animal husbandry is a strategic industry that provides the population with complete protein foods, including meat.

According to medical norms of Ukraine, meat consumption should be $82 \mathrm{~kg}$ per capita, of which $36 \mathrm{~kg}$ is beef. In this country, the principal amount of beef is obtained from extra replacement young animals of dairy breeds (Kolisnyk et al., 2018) and only a tiny part of beef breeds. Nevertheless, given the peculiarities of beef cattle breeding, it can be argued that it can become the central reserve for high-quality beef production (Kozyr \& Soloviov, 2017; Palii, 2019a).

Along with domestic beef breeds as Ukrainian, Volyn, Polissya, Southern, Simmental beef, and Ukrainian gray breeds, the most common imported breed in Ukraine is Aberdeen-Angus. Due to its precocity, well-defined meat forms, light calving, high adaptation to weather conditions, and pronounced marbling of the meat, this breed is promising for the development of beef cattle breeding (Humennyi et al., 2019; Vaz et al., 2008).

The Aberdeen-Angus breed ranks first among imported breeds by some animals. The weight of adult bulls is $800-900 \mathrm{~kg}$; that of cows is $550-650 \mathrm{~kg}$. The average daily weight gain of bulls reaches $800 \mathrm{~g}$. At the age of 18 months, bulls weigh $460 \mathrm{~kg}$ and heifers $-370 \mathrm{~kg}$.

The meat industry's specifics are that the only product is a calf, and the technology includes two stages: raising calves with sucker cows up to 8 months of age and raising young after separating from the cow. One of the advantages of beef cattle 
breeding is its economic effectiveness. Keeping cattle in the summer on pastures minimizes production costs. During the grazing period, which can last up to 200 days, almost all feed needs are satisfied by grass. Grazing is used for breeding stock, fattening animals, and young animals' maintenance (Romanzin et al., 2013; Yoshihara et al., 2013). Mostly, beef cattle are kept in a stall-walking system, which provides for the animals to stay on pastures in summer and on the sites with light rooms or sheds in winter. Keeping cattle without capital premises in any weather conditions is possible due to its ability to deposit subcutaneous fat until the cold weather and the presence of dense hair. Cattle tolerate frost and dry snow well, but rain and strong winds inflate the hair and help lower body temperature, cause disease and quickly deplete animals. In order to eliminate this negative factor, sheds and windbreaks are being built in open areas. Mounds up to $15 \mathrm{~m}$ wide and up to $1.5 \mathrm{~m}$ high made of straw are placed in open areas (Kolisnyk et al., 2017; Palii, 2019b). This retention technology minimizes the cost of beef production and makes the meat industry cost-effective.

A calf being the only, and therefore the main, product in beef cattle breeding, the main task of the industry is to obtain a calf from each cow, to preserve it and let it fully grow throughout the growing period (Brščić et al., 2018; Palii, 2020; Shchepetilnikov, 2020). In beef cattle breeding, the colostrum period is the most critical, as newborn calves are not weaned, and calves must begin to suckle on their own in the first hour of life. Untimely receipt of colostrum or its receipt in insufficient quantities is the main reason for the delayed development of calves or their death in the first days of life (Kasap et al., 2018; Palii et al., 2020; Santman-Berends et al., 2019). Stable growth of young animals during all age periods is ensured by both good nutrition and livestock technology, which affects the industry's profitability (Kravchenko et al., 2019; Palii \& Petrov, 2020). Under different housing technologies, cattle show different growth rates.

Considering the importance of stable growth of young animals throughout the growing period, the question of studying the change in weight of young animals, which in the colostrum period were grown using different techniques, turns out to be relevant.

\section{Materials and Methods}

The scientific and economic experiment was conducted on cows and calves of the Aberdeen-Angus breed at the private enterprise 'Agro-Novoselivka 2009', Novovodolazhsky district of Kharkiv region. All cows of the farm and newborn calves obtained from them were included in the experiment.

Groups were formed by the method of balanced groups in comparable periods for three years. There turned nine problem pairs' cow-calf to be found in Group I, ten pairs - in Group II and 13 pairs - in Group III.

Problem pairs' cow-calf were detected among these animals by observing cows' and calves' communication during the first hours after calving. Problem pairs' cow-calf were considered to be paired with instincts' weak manifestations: maternal instinct in cows or sucking reflex in calves.

Calving took place in the spring months in group sections for keeping cows and calves without the use of premises in all three years.

The cows and calves in Group I, including the identified problem pairs' cow-calf, were kept in group sections from birth to weaning.

A new technological element, correction sections, was introduced to keep the problem pairs' cow-calf of Groups II and III. Only problem pairs were transferred to correctional sections for their joint maintenance during the colostrum period. After identifying the problem pair, it was transferred to a separate correction section $3 \times 3 \mathrm{~m}$ in size, located in the group section for keeping cows and calves. The problem pair were kept together in the correction section until the calf began to suckle the mother independently and thoroughly, but not longer than seven days. After a complete restoration of communication between the cow and the calves, they were transferred back to the group section.

The preservation of problem calves in Group I was 33\% (3 calves), that in Group II - 90\% (9 calves), and in Group III, it was 77\% (10 calves).

According to the technology of beef cattle breeding, calves up to 7 months were raised on suckling. In all three years, the diets of experimental animals met detailed feeding standards.

The live weight of calves was determined by individual weighing in the appropriate periods: at birth, at 7, 12, 15, and 18 months. Average daily gain $(R)$ was calculated according to the formula:

where: $\mathrm{R}$ - average daily gain, g;

$$
\mathrm{R}=\mathrm{Wt}-\mathrm{Wo} / \mathrm{t} 2-\mathrm{t} 1
$$

$\mathrm{Wt}$ - live weight of the animals at the beginning of the period, $\mathrm{kg}$;

Wo - live weight of the animals at the end of the period, $\mathrm{kg}$;

t2 - the age at the end of the period, days;

t1 - the age at the beginning of the period, days.

Absolute weight gain was calculated according to the formula:

$$
\mathrm{D}=\mathrm{Wt}-\mathrm{Wo} \text {, }
$$

where: D - absolute live weight gain during a specific period, $\mathrm{kg}$;

$\mathrm{Wt}$ - live weight of the animals at the end of the period, $\mathrm{kg}$;

Wo - live weight of the animals at the beginning of the period, $\mathrm{kg}$.

The multiplicity of live weight gain was determined by dividing the live weight at 7, 12, 15, and 18 months by the newborn calves' live weight.

Student's t-test evaluated the reliability of the obtained results. The data were processed by the method of variation statistics according to M. A. Plochinskiy (1970) method using the Microsoft Excel computer program. 


\section{Results and Discussion}

The growth rate of cattle varies at different ages. Our research has again proved that the problems at the beginning of sucking affect the safety of problem calves and the subsequent intensity of their growth (Table 1).

Table 1. Dynamics of live body weight of bull-calves, $\mathrm{kg}(\mathrm{M} \pm \mathrm{m})$

\begin{tabular}{cccc}
\hline Age, months & Group I $(\mathrm{n}=2)$ & Group II $(\mathrm{n}=5)$ & Group III $(\mathrm{n}=5)$ \\
at birth & $27.5 \pm 1.5$ & $32.4 \pm 1.4$ & $33.0 \pm 1.8$ \\
7 & $151.0 \pm 3.0$ & $204.4 \pm 2.7 * * *$ & $206.2 \pm 2.3^{* * *}$ \\
12 & $262.0 \pm 2.0$ & $349.2 \pm 1.8 * * *$ & $350.0 \pm 1.0 * * *$ \\
15 & $308.0 \pm 3.0$ & $418.2 \pm 3.6 * * *$ & $420.0 \pm 2.9 * * *$ \\
18 & $356.5 \pm 2.5$ & $491.0 \pm 5.1 * * *$ & $493.6 \pm 3.2 * * *$ \\
\hline
\end{tabular}

Note: $* \star \star P>0.999$

No significant difference between the groups was found in the live weight of problem bulls at birth. At 7 months, the advantage in live weight of calves of Group II over animals of Group I was $53.4 \mathrm{~kg}$ and That of Group III - $55.2 \mathrm{~kg}$. At the age of 12 months, Group II bull-calves exceeded Group l's live weight of bull-calves by $87.2 \mathrm{~kg}$ and bull-calves of Group III - by $88 \mathrm{~kg}$, respectively. At 15 months, the predominance of Groups II and III animals over those from Group I was $110.2 \mathrm{~kg}$ and $112.0 \mathrm{~kg}$, respectively. The trend of preference for live weight of bull-calves from Groups II and III is observed at 18 months and is 134.5 in favor of Group II and $137.1 \mathrm{~kg}$ in favor of Group III.

Thus, bull-calves of Groups II and III, which were transferred to the correctional sections in the colostrum period together with the mother cows, in live weight significantly ( $P>0.999)$ surpassed the bull-calves of the I Group, which were not transferred to the correction sections, during all age periods. The imperfection of the technological elements of keeping cows and newborn calves at the beginning of suckling causes a decrease in young animals' growth rate, which is confirmed by our research. Under the same conditions, bull-calves and heifers show different growth rates. The intensity of growth of live weight of heifers is slightly lower than that of bull-calves (Table 2 ).

Table 2. Dynamics of live body weight of heifers, $\mathrm{kg}(\mathrm{M} \pm \mathrm{m})$

\begin{tabular}{|c|c|c|c|}
\hline Age, months & Group I $(n=1)$ & Group II $(n=4)$ & Group III $(n=5)$ \\
\hline at birth & 29.0 & $25.8 \pm 2.5$ & $26.2 \pm 2.0$ \\
\hline 7 & 139.0 & $197.8 \pm 4.7$ & $197.4 \pm 2.1$ \\
\hline 12 & 229.0 & $307.8 \pm 2.9$ & $307.8 \pm 1.3$ \\
\hline 15 & 261.0 & $351.3 \pm 5.7$ & $352.4 \pm 2.5$ \\
\hline 18 & 298.0 & $404.3 \pm 6.0$ & $404.8 \pm 3.2$ \\
\hline
\end{tabular}

Considering a small number of heifers in the groups, it is impossible to assess the reliability of the difference in the results. Analysis of the table data shows that with a slight difference in live weight at birth, the heifers of Groups II and III grew much better than the heifers of Group I during all age periods. The difference in the heifers' live weight at the age of 18 months between Groups I and II was $106.3 \mathrm{~kg}$ and that between Groups I and III - $106.8 \mathrm{~kg}$.

One of the critical indicators showing animal body changes is the average daily weight gain over the appropriate period (Table 3). As calves in beef cattle breeding are kept with cows during the suckling period, the average daily gain of up to 7 months depends only on their interaction.

Table 3. The average daily weight gain of bull-calves, $g(\mathrm{M} \pm \mathrm{m})$

\begin{tabular}{cccc}
\hline Age, months & Group I $(\mathrm{n}=2)$ & Group II $(\mathrm{n}=5)$ & Group III $(\mathrm{n}=5)$ \\
$0-7$ & $590 \pm 0.02$ & $820 \pm 0.01 * * *$ & $820 \pm 0.01 * * *$ \\
$7-12$ & $740 \pm 0.01$ & $970 \pm 0.02 * * *$ & $960 \pm 0.01 * * *$ \\
$12-15$ & $510 \pm 0.01$ & $770 \pm 0.03^{* * *}$ & $780 \pm 0.02 * * *$ \\
$15-18$ & $540 \pm 0.01$ & $810 \pm 0.04 * * *$ & $820 \pm 0.02 * * *$ \\
$0-18$ & $610 \pm 0.01$ & $850 \pm 0.01 * * *$ & $850 \pm 0.01 * * *$ \\
\hline
\end{tabular}

Note: $* \star * P>0.999$

A high significant difference $(P>0.999)$ between the average daily weight gain of bull-calves of Groups II and III compared with Group l's bull-calves in the period from birth to 7 months was found. According to this indicator, they exceeded the bull-calves of Group I by $230 \mathrm{~g}$. In 7-12 months, the bull-calves of Groups II and III dominated by the average daily gain, the advantage over Group I was $230 \mathrm{~g}$ and $220 \mathrm{~g}$, respectively (the significant difference is P>0.999). From 12 to 15 months, bull-calves of Group I were inferior in average daily gains to the bull-calves of Groups II and III by $260 \mathrm{~g}$ and $270 \mathrm{~g}$, respectively (P>0.999). In the last months of fattening (15-18 months) the average daily gains of bull-calves of Groups II and III prevailed by $270 \mathrm{~g}$ and $280 \mathrm{~g}$, the average daily gains of the bull-calves of Group I ( $>0.999)$. In general, for the entire period of rearing, which lasted from birth to the age of 18 months, the average daily weight gain of the bull-calves from Groups II and III reliably prevailed (P>0.999) over the average daily weight gain of bull-calves from Group I by $240 \mathrm{~g}$. 
According to the average daily weight gain in all periods, the heifers from Groups II and III also had an advantage (Table 4).

Table 4. The average daily weight gain of heifers, $g(\mathrm{M} \pm \mathrm{m})$

\begin{tabular}{|c|c|c|c|}
\hline Age, months & Group I $(n=1)$ & Group II $(n=4)$ & Group III $(n=5)$ \\
\hline $0-7$ & 520 & $820 \pm 0.01$ & $820 \pm 0.00$ \\
\hline $7-12$ & 600 & $730 \pm 0.02$ & $740 \pm 0.01$ \\
\hline $12-15$ & 360 & $480 \pm 0.04$ & $500 \pm 0.02$ \\
\hline $15-18$ & 410 & $590 \pm 0.02$ & $580 \pm 0.01$ \\
\hline $0-18$ & 500 & $700 \pm 0.01$ & $700 \pm 0.00$ \\
\hline
\end{tabular}

For the entire rearing period, the heifers' average daily weight gain in Groups II and III exceeded that of the heifers in Group I by $200 \mathrm{~g}$, which is quite a significant difference.

The bull calves' absolute weight gain was studied (Table 5).

Table 5. Absolute body weight gain of bull-calves, $\mathrm{kg}(\mathrm{M} \pm \mathrm{m})$

\begin{tabular}{|c|c|c|c|}
\hline Age, months & Group I $(n=2)$ & Group II (n=9) & Group III $(n=10)$ \\
\hline $0-7$ & $123.5 \pm 4.5$ & $172.0 \pm 3.0 * * \star$ & $173.2 \pm 3.1 * * *$ \\
\hline $7-12$ & $111.0 \pm 1.0$ & $144.8 \pm 2.7^{* \star *}$ & $143.8 \pm 1.4^{\star \star *}$ \\
\hline $12-15$ & $46.0 \pm 1.0$ & $69.0 \pm 2.7 * \star \star$ & $70.0 \pm 2.0 * \star \star$ \\
\hline $15-18$ & $48.5 \pm 0.5$ & $72.8 \pm 3.2^{\star \star *}$ & $73.6 \pm 1.6 * * *$ \\
\hline $0-18$ & $329.0 \pm 4.0$ & $458.6 \pm 4.9 * \star *$ & $460.6 \pm 3.5^{\star \star *}$ \\
\hline
\end{tabular}

Note: $* \star * P>0.999$

The absolute weight gain of bull-calves during the suckling period was higher by $48.5 \mathrm{~kg}$ in Group II and $49.7 \mathrm{~kg}$ Group III compared with Group I's animals. From 7 to 12 months, the bull-calves of Group I was inferior to the bull-calves of Group II by $33.8 \mathrm{~kg}$ and the bulls of Group III - by $32.8 \mathrm{~kg}$. From 12 to 15 months, the advantage in favor of the bull-calves of Groups II and III compared with the animals of Group I was $23 \mathrm{~kg}$ and $24 \mathrm{~kg}$, respectively. In the last three months (15-18 months), the animals' absolute weight gain slightly increased compared to the previous period. The animals of Groups II and III in absolute weight gain exceeded Group I's animals by $24.3 \mathrm{~kg}$ and $25.1 \mathrm{~kg}$, respectively. Thus, in terms of absolute weight gain, the bull-calves of Groups II and III predominated during the whole growing period, the advantage in their favor compared to the animals of Group I was $129.6 \mathrm{~kg}$ and $131.6 \mathrm{~kg}$, respectively.

The heifers' highest absolute weight gain was observed until 12 months of age and then decreased (Table 6).

Table 6. Absolute body weight gain of heifers, $\mathrm{kg}(\mathrm{M} \pm \mathrm{m})$

\begin{tabular}{|c|c|c|c|}
\hline Age, months & Group I $(n=1)$ & Group II $(n=4)$ & Group III $(n=5)$ \\
\hline $0-7$ & 110.0 & $172.1 \pm 2.5$ & $171.2 \pm 0.7$ \\
\hline $7-12$ & 90.0 & $109.9 \pm 2.3$ & $110.4 \pm 1.4$ \\
\hline $12-15$ & 32.0 & $43.5 \pm 3.4$ & $44.6 \pm 1.4$ \\
\hline $15-18$ & 37.0 & $53.0 \pm 1.5$ & $52.4 \pm 1.1$ \\
\hline $0-18$ & 269.0 & $378.5 \pm 3.8$ & $378.6 \pm 2.1$ \\
\hline
\end{tabular}

The highest absolute weight gain of the heifers from birth to 18 months of age was observed in Groups II and III heifers. According to this indicator, Group I's animals were inferior to the animals of Groups II and III by $109.5 \mathrm{~kg}$ and $109.6 \mathrm{~kg}$, respectively. According to that of the calves at birth, the coefficient of body weight gain of the young animals gives a complete picture of the growth rate of the animals (Table 7).

Table 7. The multiplicity of body weight gain of bull-calves, times $(\mathrm{M} \pm \mathrm{m})$

\begin{tabular}{|c|c|c|c|}
\hline Age, months & Group I $(n=2)$ & Group II $(n=5)$ & Group III $(n=5)$ \\
\hline 7 & $5.5 \pm 0.4$ & $6.4 \pm 0.3$ & $6.3 \pm 0.3$ \\
\hline 12 & $9.6 \pm 0.6$ & $10.9 \pm 0.4$ & $10.7 \pm 0.5$ \\
\hline 15 & $11.4 \pm 0.7$ & $13.0 \pm 0.5$ & $12.9 \pm 0.6$ \\
\hline 18 & $13.0 \pm 0.8$ & $15.3 \pm 0.6$ & $15.1 \pm 0.7$ \\
\hline
\end{tabular}

The studies have shown higher rates of body weight gain of the bull-calves at all age periods in Groups II and III animals. The multiplicity of weight gain of the bull-calves at 18 months was 2.3 times higher in Group II animals than Group I and 2.1 times in Group III animals, respectively.

According to the coefficients of body weight gain, Groups II and III's heifers prevailed over Group I (Table 8). 
Table 8. A multiplicity of body weight gain of heifers, times $(\mathrm{M} \pm \mathrm{m})$

\begin{tabular}{cccc}
\hline Age, months & Group I $(\mathrm{n}=1)$ & Group II $(\mathrm{n}=4)$ & Group III $(\mathrm{n}=5)$ \\
7 & 4.8 & $7.9 \pm 0.6$ & $7.7 \pm 0.5$ \\
12 & 7.9 & $12.3 \pm 1.1$ & $12.0 \pm 0.9$ \\
15 & 9.0 & $14.0 \pm 1.2$ & $13.8 \pm 1.0$ \\
18 & 10.3 & $16.1 \pm 1.3$ & $15.8 \pm 1.2$ \\
\hline
\end{tabular}

The data in the table show that according to the multiplicity of body weight gain of the heifers during all age periods, the advantage was 5.8 times and 5.5 times in favor of Groups II and III than the animals from Group I. Our results can be compared with the study of the Bulgarian scientists. According to them, calves of the Aberdeen-Angus breed weigh at birth $31-32 \mathrm{~kg}$. The average live weight at weaning is $204 \mathrm{~kg}$ (Nikolov \& Karamfilov, 2020). Our experiment showed that the average live weight of bull-calves at birth is $31 \mathrm{~kg}$, and that of heifers - $28 \mathrm{~kg}$.

The literature data indicate an increase in animals' live body weight at later periods of rearing compared to the sucking period. The generalized indicator of livestock growth is live body weight, and it shows the peculiarities of the formation of animals. Only healthy and fully developed animals can show high productivity (Palii et al., 2021; Skliarenko, 2018). The maximum average daily weight gain of animals is observed from birth to the age of 18 months, which is identic with our research. The lowest average daily weight gain of the cattle is observed from 18 to 24 months. Average daily weight gain also decreases with age. By the age of 12 months, animal growth intensity is much higher compared to subsequent periods (Kozyr, 2020).

Nosok et al. (2020), Pesonen et al. (2012), and Tsvigun et al. (2020) focused on increasing the weight gain and productivity of livestock by crossing animals of different origins. At birth, crossbreed cattle predominate purebred ones; they are well developed and have a balanced physique. For example, crossbreed young animals of Aberdeen-Angus and Ukrainian blackand-white dairy breeds at 18 months reach $490 \mathrm{~kg}$. The advantage of crossbreed animals over purebreds reaches $20 \%$ (Tsvigun et al., 2020). Crossbreeds of Ukrainian black-spotted dairy breed with Belgian blue breed predominate by $6 \%$ purebred animals of Ukrainian black-spotted dairy breed. The animals are characterized by dense muscles, a well-developed back of the torso, a deep and broad chest, and strong limbs (Nosok et al., 2020).

When inseminating Simmental cows with elite bulls, an increase in animals' live weight at all ages has been found. The animals met or exceeded the breed standard (Dankiv et al., 2020). According to Shuplyk \& Shcherbatiuk (2020), the Aberdeen-Angus beef breed's productivity can be influenced by the animals' linear affiliation. Bulls from different lines showed different growth rates from birth to 12 months. The bulls of the Southoma Extra line outperformed other animals in terms of average daily and absolute growth. In different periods of breeding, bulls showed different growth rates, which correlates with our research. The growth and development of animals are influenced by many factors: the live weight of calves at birth, feeding, and calving season of cows (Osipenko et al., 2018). For example, Aberdeen-Angus calves born in autumn reach a higher live weight at weaning than calves born in previous months. The advantage in favor of calves born in autumn is $13 \mathrm{~kg}$ (Jurco et al., 2020). Our research has shown that the growth of young animals is influenced by the technology of keeping cows and calves during the colostrum period. Calves with the problems at the beginning of suckling and were not given sufficient attention due to the imperfection of the content's technological elements lagged in growth throughout the rearing period (up to 18 months). This gives reason to assert the relationship between the technology of keeping cows and calves during the colostrum period and young animals' growth.

\section{Conclusion}

It has been found that with the introduction of a new technological element of keeping of problem pairs' cow-calf (Groups II and III), namely their transfer to correction sections for joint maintenance during the colostrum period, the growth rate of these calves were much higher compared to those for which no correction sections were used. When using correction sections for calves in the colostrum period, high growth intensity of young animals was observed throughout the whole rearing period. The difference in live weight of bull-calves at the age of 18 months was in favor of animals from Groups II and III, $27 \%$ and $28 \%$ ( $P>0.999)$, respectively. In terms of average daily increments, for the entire growing period, the bull-calves from Groups II and III dominated the animals from Group I by $28 \%$ and by $28 \%$ and $29 \%$, respectively, in absolute terms ( $P>0.999)$.

Animals of groups II and III dominated the live weight of heifers at the age of 18 months; the advantage in their favor compared to animals of Group I was $26 \%$. The average daily and absolute gains in heifers of groups II and III were higher by $29 \%$ compared with Group I. When compared by live weight at the age of 18 months, the heifers from groups II and III had an advantage of $26 \%$ compared to the animals from Group I. The average daily and absolute gains in these heifers were $29 \%$ greater than the heifers from Group I.

\section{References}

Alhas, E. N., Bozoğlu, M., \& Bilgiç, A. (2020). The impact of livestock supports on production and income of the beef cattle farms: a case of Samsun province Turkey. Journal of Agricultural Sciences, 26, 117-129. https://doi.org/10.15832/ankutbd.487493

Brščić, M., Kirchner, M. K., Knierim, U., Contiero, B., Gottardo, F., Winckler, C., \& Cozzi, G. (2018). Risk factors associated with beef cattle losses on intensive fattening farms in Austria, Germany and Italy. The Veterinary Journal, 239, 48-53. https://doi.org/10.1016/j.tvjl.2018.08.002

Dankiv, V., Dyachenko, O., Pavlyshak, Y., \& Kohut, M. (2020). Exterior features and milk productivity of cows of the Simmental combined (milkmeat) breed in TzOV "Litynske". Foothill and mountain agriculture and animal husbandry, 68(1), 189-204. https://doi.org/10.32636/01308521.2020-(68)-1-14 
Humennyi, V., Shalovylo, S., Gutyj, B., \& Boiko, A. (2019). Ethological observations of reproductive qualities of Aberdeen-Angus and Grey Ukrainian breed in the conditions of forest-steppe and steppe zones of Ukraine. Scientific Messenger of LNU of Veterinary Medicine and Biotechnologies. Series: Agricultural Sciences, 21(90), 98-103. https://doi.org/10.32718/nvlvet-a9017

Jurco, E., Onaciu, G., Suciu, S., Jurco, A., Mot, A., \& Jurco, S. (2020). Preweaning growth performances of Aberdeen Angus calves. Rom Biotechnol Lett, 25(5), 1969-1976. https://doi.org/10.25083/rbl/25.5/1969.1976

Kasap, S., Temizel, E. M., Akgul, G., \& Senturk, S. (2018). Practical Field Applications for Reducing Infectious Diseases of 0-6 Months Calves and Their Results. Harran Üniversitesi Veteriner Fakültesi Dergisi, 7(1), 102-107. https://doi.org/10.31196/huvfd.470976

Kolisnyk, O., Prudnikov, V., Kryvoruchko, Y., \& Nahornyi, S. (2017). Technological peculiarities of the content of the Aberdeen-Angussian bread in the winter period at the open sites. Bulletin of Poltava State Agrarian Academy, 4, 67-71. https://doi.org/10.31210/visnyk2017.04.13

Kolisnyk, O., Uhnivenko, A., Antoniuk, T., \& Prudnikov, V. (2018). Meat productivity of cattle. CP Comprint, 429.

Korobkov, E., Kozlov, V., Shalaev, A., \& Korolev, A. (2020). Modern state of the production organization of beef cattle breeding in the Russian Federation. IOP Conf. Series: Earth and Environmental Science, 659, 1-7. https://doi:10.1088/1755-1315/659/1/012105

Kozyr, V. (2020). Meat productivity of calves of Simmental breed in the conditions of global climate change in the Steppe zone of Ukraine. Bulletin of Agricultural Science, 98(9), 21-29. https://doi.org/10.31073/agrovisnyk202009-03

Kozyr, V., \& Soloviov, M. (2017). Comparative Evaluation Of Factory Types Ukrainian Meat Breed. Scientific reports of NULES of Ukraine, 6(70), 1-11. https://doi.org/10.31548/dopovidi2017.06.012

Kravchenko, Yu., Prusova, L., Zolotarev, A., Yeletskaya, L., \& Timchenko, L. (2019). Environment temperature as a factor of influence on the cattle productivity. Naukovo-tekhnichnyi biuleten Instytutu tvarynnytstva NAAN, 12, 136-146. https://doi.org/10.32900/2312-8402-2019-121-136$\underline{146}$

Nikolov, V., \& Karamfilov, S. (2020). Growth of female calves of the Aberdeen Angus cattle breed reared in an organic farm. Scientific papersseries d-animal science, 63(1), 60-66.

Nosok, S., Kryvoruchko, Y., \& Zandaryan, V. (2020). Use of Belgian blue beef cattle by industrial crossing in the eastern region of Ukraine. Veterinary Science, Technologies of Animal Husbandry and Nature Management, 5, 110-115. https://doi.org/10.31890/vttp.2020.05.20

Osipenko, T. L., Admina, N. G., Palii, A. P., Chechui, H. F., \& Mihalchenko, S. A. (2018). Influence of the level feeding high-productive cows on obtaining biosafety products. Ukrainian Journal of Ecology, 8(4), 189-194.

Palii, A. (2020). How to successfully raise calves in winter? Journal of Cows, 1, 30-31. (In Ukrainian)

Palii, A. P., Osipenko, T. L., Syromiatnikov, P. S., Boyko, Y. A., Nechyporenko, V. V., Levchenko, I. V., Ostapenko, V. I., Prykhodko, M. F., Korzh, O. V., Popsuy, V. V., \& Paliy, A. P. (2021). Influence of cattle breed combinations on milk production: results of the Analysis of Variance. Ukrainian Journal of Ecology, 11(1), 25-31. doi:10.15421/2020 304

Palii, A. P., \& Palii, A. P. (2019). Technical and technological innovations in dairy cattle. Monograph. Kharkiv: Mis'kdruk. ISBN 978-617-619-207-7 (In Ukrainian)

Palii, A., \& Petrov, A. (2020). Analysis of options for keeping cattle on deep straw litter. Journal of Cows, 9-10(19-20), 33-34. (In Ukrainian)

Palii, A. P., Rodionova, K. O., Paliy, A. P., Kushch, L. L., Matsenko, O. V., Kambur, M. D., Zamaziy, A. A., Plyuta, L. V., Baidevliatov, Y. A., Kolechko, A. V., \& Honcharenko, H. O. (2020). Effect of colostral bacterial contemination on the calves. Ukrainian Journal of Ecology, 10(3), 76-82. doi:10.15421/2020 136

Palii, A. P. (2019a). Strategy of innovative development of animal husbandry. Bulletin of Kharkiv National Technical University of Agriculture Petra Vasilenko, 201: Innovative projects in the field of technical service of machines, 141-145. (In Ukrainian)

Palii, A. (2019b). Systems of keeping cattle on pastures. Journal of Cows, 5, 34-35. (In Ukrainian)

Pesonen, M., Honkavaara, M., \& Huuskonen, A. (2012). Effect of breed on production, carcass traits and meat quality of Aberdeen Angus, Limousin and Aberdeen Angus $\times$ Limousin bulls offered a grass silage-grain-based diet. Agricultural and Food Science, 21(4), 361-369. https://doi.org/10.23986/afsci.6520

Romanzin, A., Corazzin, M., Piasentier, E., \& Bovolenta, S. (2013). Effect of rearing system (mountain pasture vs. indoor) of Simmental cows on milk composition and Montasio cheese characteristics. The Journal of Dairy Research, 80(4), 390-399. doi:10.1017/S0022029913000344

Santman-Berends, I. M. G. A., Schukken, Y. H., \& van Schaik, G. (2019). Quantifying calf mortality on dairy farms: Challenges and solutions. Journal of Dairy Science, 102(7), 6404-6417. https://doi.org/10.3168/jds.2019-16381

Shchepetilnikov, Yu. (2020). The use of ferment preparations to increase the defensive functions and to decrease the stress influence on calves. Ukrainian Black Sea Region Agrarian Science, 2(106), 80-86. doi:10.31521/2313-092X/2020-2(106)-9

Shuplyk, V., \& Shcherbatiuk, N. (2020). Evaluation of growth of bulls of different lines of Aberdeen-Angus breed under 12 months of age. InterConf, 36, 1219-1244. (In Ukrainian)

Skliarenko, Yu. (2018). Research of trends of change of living weight of repair heifers of the Ukrainian storm dairy breed and their influence for further dairy productivity. Foothill and mountain agriculture and animal husbandry, 64, 199-209. https://www.doi.org/10.32636/01308521.2018-(64)-18

Tsvigun, A., Shuplik, V., Kasprov, R., \& Scherbatyuk, N. (2020). Biological features of growth, development and productivity indicators of animals obtained from crossing of cattle of different breeds. Podilian Bulletin: agriculture, engineering, economics, 32, 81-89. https://doi.org/10.37406/2706-9052-2020-1-10

Vaz, F. N., Restle, J., Metz, P. A. M., \& Moletta, J. L. (2008). Características de carcaça de novilhos aberdeen angus. Ciência Animal Brasileira, 9(3), 590-597. https://doi.org/10.5216/cab.v9i3.930

Yoshihara, Y., Mizuno, H., Ogura, S., Sasaki, T., \& Sato, S. (2013). Increasing the number of plant species in a pasture improves the mineral balance of grazing beef cattle. Animal Feed Science and Technology, 179(1-4), 138-143. https://doi.org/10.1016/j.anifeedsci.2012.11.009

\section{Citation:}

Dydykina, A.I., Prudnikov, V.H., Kolisnyk, O.I., Vasylieva, Y.O., Palii, A.P., Paliy, A.P., Petrov, A.M. (2021). Influence of keeping technology on the weight gain of the Aberdeen-Angus breed young animals in the colostrum period.

Ukrainian Journal of Ecology, 11 (2), Ecological Risk Assessment, 27-32.

(cc) EY This work is licensed under a Creative Commons Attribution 4.0. License 